\title{
HEALTH BELIEF MODEL ON SEXUAL BEHAVIOR ISSUES AMONG PRISONERS AT PRISON IN PEKALONGAN, CENTRAL JAVA
}

\author{
Liliana Dwi Pranita'), Argyo Demartoto²), Bhisma Murti3) \\ 1)Masters Program in Public Health, Sebelas Maret University \\ 2)Faculty of Social and Political Sciences, Sebelas Maret University \\ 3)Faculty of Medicine, Sebelas Maret University
}

\begin{abstract}
Bacground: One of the basic human needs to be fulfilled is sexual need. Prisoners face problem in their sexual need fulfilment and freedom, due to the prison's diciplinary system, including supervison, strict disciplinary mechanism, and enactment of spatial division between men and women. As a consequence, there often occur perverted sexual behaviors, including homosexuality. This study aimed to analyze the sexual behavior issues among prisoners at prison using Health Belief Model.

Subjects and Method: This was a qualitative descriptive study with phenomenological approach. The main key informants in this study were prisoners having imprisoned for one year or more and officers at Class IIA prison, in Pekalongan, Central Java. The supporting informants included health personnel (doctors and nurses) at Class IIA prison clinic.

Results: All informants reported that they were susceptible to engage in risky sexual behaviors in order to fulfil their sexual need, such as masturbation and homosexuality. The psychological adverse effects they had experienced included fear and feeling of embarrassment their perverted sexual behaviors were recognized by others. The informants reported that they did not have self-efficacy in coping with sexual need issues while in prison.

Conclusion : The imprisonment system has an impact on the way inmates meet their sexual needs through masturbation. The role of prison officials is urgently needed to enable prisoners to address the problems of their biological needs through beneficial activities while in prison.
\end{abstract}

Keywords: prisoners, sexual behaviors, Health Belief Model

Correspondence: Liliana Dwi Pranita. Masters Program in Public Heath, Sebelas Maret University, Jl. Ir. Sutami 36 A, Surakarta 57126, Central Java. Email: lilin_quina@yahoo.com. Mobile: +6285647000303. 